\title{
GENETIC DISTANCE BETWEEN PHEROMONE STRAINS OF THE EUROPEAN CORN BORER, OSTRINIA NUBILALIS: DIFFERENT CONTRIBUTION OF VARIABLE SUBSTRATE, REGULATORY AND NON REGULATORY ENZYMES
}

\author{
R. CIANCHI*, S. MAINI, $\dagger$ and L. BULLINI* \\ * Institute of Genetics, University of Rome; †Institute of Entomology, University of \\ Bologna
}

Received 22.v.80

\begin{abstract}
SUMMARY
Genetic divergence between two forms of Ostrinia nubilalis, which were characterized by a different composition of the sex pheromone, was studied on the basis of 30 gene-enzyme systems. Nei's measure of standard genetic distance between the forms was $D=0.024$, strikingly different from the value of $D=0.002$ previously obtained by Harrison and Vawter on 10 enzyme loci between populations genetically homogeneous with those presently studied. In order to examine the discrepancy, and to test Sarich's hypothesis of a correlation between metabolic role of enzymes and their rate of evolution, the sample of 30 loci was subdivided into two classes: 14 loci coding for variable-substrate and regulatory (sensu Johnson, 1974) enzymes on the one hand and 16 loci coding for nonregulatory enzymes on the other. The mean values of genetic distance calculated separately for the two classes of enzymes were significantly different: $D_{f}=0.056$ and $D_{s}=0.004$ respectively. The ratio $D_{f} / D_{s}$ is 14 , a value of the same magnitude as found in various taxa at the beginning of their process of divergence, as indicated by recent data on both vertebrates and invertebrates.

The data confirm Sarich's hypothesis of a bimodality in the rate of evolution of different classes of enzymes, and explain the difference between our value of the mean genetic distance and that obtained by Harrison and Vawter, who studied mainly non-regulatory enzymes. They confirm the importance of the choice of loci in evaluating genetic divergence. Mean values of genetic distance may be meaningless if they do not take into account the proportions of loci with different metabolic roles.
\end{abstract}

\section{INTRODUCTION}

OstRINIA NUbILALIS Hübner (Lepidoptera, Pyralidae), the European corn borer, is one of the most destructive pests of corn. It is a cosmopolitan species, originally distributed in Europe and from there introduced into America, where it has now spread to most of Southern Canada and the United States, east of the Rocky Mountains. The insect has a pheromone communication system. The pheromone, secreted by the females, consists of a blend of the two geometrical isomers, $Z$ and $E$, of 11 -tetradecenyl acetate (11-tda) (Klun and Robinson, 1971; Roelofs et al., 1972). In most countries of Europe and North America males are preferentially attracted by the $97: 3 Z: E$ blend of 11 -tda. In Italy and New York state the optimal response is given by the $3: 97 Z: E$ mixture. In a few cases the two forms have been found in sympatry, with a proportion of the males (presumably hybrids) attracted by a 50:50 $Z: E$ blend (Klun and Cooperators, 1975; 
Cardè et al., 1975; Anglade, 1974). Hybridization, and the Mendelian heredity of the composition of isomers of 11 -tda, has been confirmed by gas chromatography and by biossays (Klun and Maini, 1979). The genetic distance between the two forms, estimated on the basis of 10 gene-enzyme systems, has been reported to be very low: $D=0.002$ (Harrison and Vawter, 1977; Cardè et al., 1978).

It has been stressed recently (Sarich, 1977; Zimmerman et al., 1978; Cianchi et al., 1978) that genetic distance calculations are affected by the contribution of two different classes of enzymes: variable substrate and regulatory enzymes (sensu Johnson, 1974) being generally variable and rapidly-evolving, and non regulatory enzymes being less variable and slowly-evolving (see also Powell, 1975).

In this paper we extend the study of genetic divergence between the two forms of $O$. nubilalis to a sample of 30 gene-enzyme systems (comprising about equal proportions of the two classes of enzymes) in order to investigate the correlation between the metabolic roles of enzymes and their rate of evolution, in a species that is presumably at the beginning of a speciation process (Cardè et al., 1978).

\section{MATERIALS AND METHODS}

Two strains of $O$. nubilalis have been assayed: one from Ankeny, Iowa, attracted by the $97: 3 Z: E$ blend of 11-tda; and one from Geneva, New York, responding to the $3: 97$ blend.

Standard horizontal starch gel electrophoresis was performed on the thorax of single individuals, crushed in $0.02 \mathrm{ml}$ of distilled water. The following gene-enzyme systems have been assayed: octanol dehydrogenase $(O d h)$, sorbitol dehydrogenase $(S d h-1, S d h-2), \alpha$-glycerophosphate dehydrogenase $(\alpha-G p d h)$, malate dehydrogenase (Mdh-1, $M d h-2)$; malic enzyme $(\mathrm{Me})$, isocitrate dehydrogenase (Idh-1, Idh-2), 6-phosphogluconate dehydrogenase $(6 \mathrm{Pgdh})$, glucose-6-phosphate dehydrogenase $(G 6 p d h)$, glucose dehydrogenase (Gldh-1, Gldh-2, Gldh-3), glutamate dehydrogenase $(G d h)$, lactate dehydrogenase $(L d h)$, aldehyde oxidase $(A o)$, glyceraldehyde-3-phosphate dehydrogenase (G3pdh), xanthine dehydrogenase $(X d h)$, superoxide dismutase (Sod), glutamateoxaloacetate transaminase (Got-1, Got-2), adenylate kinase (Adk), phosphoglucomutase $(P g m)$, aldolase $(A l d-1, A l d-2)$, leucine amino peptidase (Lap-1, Lap-2), triose phosphate isomerase (Tpi) and glucose phosphate isomerase $(P g i)$. The staining techniques are, with some modifications, those described by Ayala et al., 1972 (ODH, MDH, ME, IDH, G3PDH, SOD, ADK, PGM, ALD, TPI), Harris and Hopkinson 1977 (AO, GLDH, $\alpha-\mathrm{GPDH})$, Shaw and Prasad, 1970 (SDH, GDH, LDH) and Selander et al., 1971 (6PGDH, G6PDH, XDH, GOT, LAP, PGI). As in a previous paper (Cianchi et al., 1978), we have considered the following loci: $M e$, mithochondrial Idh, Gldh-1, Gldh-2, Gldh-3, Ao, G3pdh, Xdh, Adk, Pgm, Lap-1, Lap-2, Pgi, G6pdh, as coding for variable-substrate or regulatory enzymes; and: $O d h, S d h-1, S d h-2, \alpha-G p d h, M d h-1, M d h-2$, cytoplasmic Idh, 6Pgdh, Gdh, Ldh, Sod, Got-1, Got-2, Ald-1, Ald-2, Tpi, as coding for non-regulatory enzymes.

Isozymes were numbered in order of decreasing mobility from the most anodal. The most common allele was designated with exponent 1 , and the 
others with a number corresponding to the distance in $\mathrm{mm}$ from the most common (for instance, an allele migrating $10 \mathrm{~mm}$ faster than the most common is designated $1 \cdot 10$, while one running $10 \mathrm{~mm}$ slower is designated $0.90)$.

Nei's measures of standard genetic distance $(D)$ and identity $(I)$ were used for the evaluation of genetic differentiation (Nei, 1972, 1975).

\section{RESUlTS AND DISCUSSION}

Homogeneity tests between our laboratory populations and the field samples previously studied by Harrison and Vawter (1977), performed on the 10 enzyme loci they analyzed, showed a high degree of similarity. The value of $D$ between the $97: 3$ pheromone strains is 0.001 , and that between the $3: 97$ strains is $0.005 \pm 0 \cdot 001$.

We have calculated the genetic distance between our pheromone strains on the basis of all the 30 enzyme loci that we have analyzed. Allele

\section{TABLE 1}

Allele frequencies at 14 loci coding for variable-substrate or regulatory enzymes in two pheromone

\begin{tabular}{|c|c|c|c|c|c|c|c|}
\hline Locus & Allele & $\begin{array}{l}\text { Popula- } \\
\text { tions } \\
\text { Iowa }\end{array}$ & strains of & $\begin{array}{l}\text { nubilalis } \\
\text { Locus }\end{array}$ & Allele & $\begin{array}{l}\text { Popula- } \\
\text { tions } \\
\text { Iowa }\end{array}$ & New York \\
\hline \multirow[t]{2}{*}{$M e$} & 1 & $1 \cdot 00$ & $1 \cdot 00$ & \multirow[t]{3}{*}{$X d h$} & $1 \cdot 05$ & 0.06 & 0.08 \\
\hline & $\mathrm{N}$ & 34 & 32 & & & 0.94 & 0.92 \\
\hline \multicolumn{2}{|c|}{ mean het. } & - & - & & $\mathrm{N}$ & 26 & 31 \\
\hline \multirow[t]{6}{*}{$I d h-2$} & $1 \cdot 08$ & - & 0.01 & \multicolumn{2}{|c|}{ mean het. } & 0.11 & $0 \cdot 16$ \\
\hline & $1 \cdot 04$ & $0 \cdot 27$ & 0.21 & \multirow[t]{2}{*}{$A d k$} & 1 & $1 \cdot 00$ & $1 \cdot 00$ \\
\hline & 1 & $0 \cdot 72$ & 0.78 & & $\mathrm{~N}$ & 21 & 20 \\
\hline & 0.96 & 0.01 & $\overline{-}$ & \multicolumn{2}{|c|}{ mean het. } & - & - \\
\hline & $\mathbf{N}$ & 91 & 95 & \multirow{2}{*}{ Pgm } & 1 & $1 \cdot 00$ & $1 \cdot 00$ \\
\hline & & $0 \cdot 42$ & $0 \cdot 34$ & & $\mathbf{N}$ & 47 & 44 \\
\hline \multirow[t]{4}{*}{ Gldh-1 } & $1 \cdot 05$ & 0.17 & 0.06 & \multicolumn{2}{|c|}{ mean het. } & - & - \\
\hline & 1 & 0.53 & 0.94 & \multirow[t]{4}{*}{ Lap-1 } & 1.04 & - & 0.35 \\
\hline & 0.97 & $0 \cdot 30$ & - & & 1.02 & $0 \cdot 14$ & $0 \cdot 15$ \\
\hline & $\mathbf{N}$ & 18 & & & 1 & 0.86 & 0.50 \\
\hline mean het. & & $0 \cdot 61$ & $0 \cdot 12$ & & $\mathbf{N}$ & 11 & 10 \\
\hline \multirow[t]{4}{*}{ Gldh-2 } & $1 \cdot 06$ & - & 0.04 & \multicolumn{2}{|c|}{ mean het. } & $0 \cdot 27$ & 0.60 \\
\hline & $1 \cdot 04$ & $0 \cdot 33$ & $\begin{array}{l}0.17 \\
0.79\end{array}$ & \multirow[t]{4}{*}{ Lap-2 } & $1 \cdot 05$ & 0.05 & - \\
\hline & $\begin{array}{l}1 \\
N\end{array}$ & $0 \cdot 67$ & $\begin{array}{r}0 \cdot 79 \\
39\end{array}$ & & 1.03 & 0.35 & 0.06 \\
\hline & $\mathbf{N}$ & $\begin{array}{l}31 \\
0.42\end{array}$ & 0.36 & & 1 & 0.60 & 0.94 \\
\hline \multirow{3}{*}{ Gldh-3 } & & 0.42 & $0 \cdot 81$ & & $\mathbf{N}$ & 10 & 9 \\
\hline & 1 & & $\begin{array}{l}0.81 \\
0.19\end{array}$ & \multicolumn{2}{|c|}{ mean het. } & 0.40 & $0 \cdot 11$ \\
\hline & $\begin{array}{l}0.97 \\
\mathrm{~N}\end{array}$ & $\begin{array}{r}0.45 \\
19\end{array}$ & 18 & \multirow{2}{*}{$P g i$} & $1 \cdot 05$ & $0 \cdot 29$ & 0.06 \\
\hline mean het. & & 0.58 & $0 \cdot 28$ & & 1 & 0.66 & 0.63 \\
\hline \multirow{6}{*}{ Ao } & $1 \cdot 06$ & 0.26 & 0.22 & & $\begin{array}{l}0.94 \\
N\end{array}$ & $\begin{array}{r}0.05 \\
55\end{array}$ & $\begin{array}{r}0 \cdot 31 \\
91\end{array}$ \\
\hline & 1 & $0 \cdot 54$ & 0.58 & \multicolumn{2}{|c|}{ mean het. } & 0.45 & 0.53 \\
\hline & 0.95 & $0 \cdot 16$ & $0 \cdot 20$ & \multirow[t]{3}{*}{ G6pdh } & 1 & $1 \cdot 00$ & 0.99 \\
\hline & 0.92 & 0.02 & - & & 0.97 & - & $0 \cdot 01$ \\
\hline & 0.88 & 0.02 & - & & $\mathbf{N}$ & 34 & 36 \\
\hline & $\mathbf{N}$ & 25 & 40 & \multirow{2}{*}{\multicolumn{2}{|c|}{ mean het. }} & - & 0.03 \\
\hline mean het. & & 0.52 & 0.62 & & & & \\
\hline \multirow[t]{3}{*}{$G 3 p d h$} & 1 & 0.92 & $0 \cdot 72$ & & & & \\
\hline & null & $0 \cdot 08$ & $0 \cdot 29$ & & & & \\
\hline & $\mathbf{N}$ & 26 & 36 & & & & \\
\hline mean het. & & $0 \cdot 15$ & 0.42 & & & & \\
\hline
\end{tabular}


TABLE 2

Allele frequencies at 16 loci coding for non regulatory enzymes in two pheromone strains of $\mathrm{O}$. nubilalis

\begin{tabular}{|c|c|c|c|c|c|c|c|}
\hline Locus & Allele & $\begin{array}{l}\text { Popula- } \\
\text { tions } \\
\text { Iowa }\end{array}$ & New York & Locus & Allele & $\begin{array}{l}\text { Popula- } \\
\text { tions } \\
\text { Iowa }\end{array}$ & New York \\
\hline \multirow[t]{2}{*}{ Odh } & 1 & $1 \cdot 00$ & $1 \cdot 00$ & \multirow[t]{2}{*}{$G d h$} & 1 & 1.00 & $1 \cdot 00$ \\
\hline & $\mathrm{N}$ & 8 & 14 & & $\mathrm{~N}$ & 24 & 29 \\
\hline \multicolumn{2}{|c|}{ mean het. } & - & - & \multicolumn{2}{|c|}{ mean het. } & - & - \\
\hline \multirow[t]{2}{*}{$S d h-1$} & 1 & $1 \cdot 00$ & $1 \cdot 00$ & \multirow[t]{2}{*}{$L d h$} & 1 & 1.00 & 1.00 \\
\hline & $\mathrm{N}$ & 16 & 15 & & $\mathbf{N}$ & 19 & 36 \\
\hline \multicolumn{2}{|c|}{ mean het. } & - & 一 & \multicolumn{2}{|c|}{ mean het. } & - & - \\
\hline \multirow[t]{3}{*}{$S d h-2$} & $1 \cdot 05$ & 0.54 & $0 \cdot 32$ & \multirow[t]{2}{*}{ Sod } & 1 & $1 \cdot 00$ & $1 \cdot 00$ \\
\hline & 1 & 0.46 & $0 \cdot 68$ & & $\mathrm{~N}$ & 39 & 74 \\
\hline & $\mathbf{N}$ & 26 & 28 & \multicolumn{2}{|c|}{ mean het. } & - & - \\
\hline \multicolumn{2}{|c|}{ mean het. } & 0.44 & $0 \cdot 36$ & \multirow[t]{3}{*}{ Got-1 } & 1 & 0.98 & $1 \cdot 00$ \\
\hline \multirow[t]{2}{*}{$\alpha-G p d h$} & 1 & $1 \cdot 00$ & $1 \cdot 00$ & & 0.94 & $0 \cdot 02$ & - \\
\hline & $\mathrm{N}$ & 20 & 25 & & $\mathbf{N}$ & 34 & 31 \\
\hline \multicolumn{2}{|c|}{ mean het. } & - & - & \multicolumn{2}{|c|}{ mean het. } & 0.03 & - \\
\hline \multirow[t]{3}{*}{$M d h-1$} & $1 \cdot 05$ & - & 0.03 & \multirow{3}{*}{ Got-2 } & $1 \cdot 05$ & $0 \cdot 02$ & - \\
\hline & 1 & $1 \cdot 00$ & 0.97 & & 1 & 0.98 & $1 \cdot 00$ \\
\hline & $\mathrm{N}$ & 48 & 58 & & $\mathrm{~N}$ & 34 & 31 \\
\hline \multicolumn{2}{|c|}{ mean het. } & - & 0.07 & \multicolumn{2}{|c|}{ mean het. } & 0.03 & - \\
\hline \multirow[t]{3}{*}{$M d h-2$} & 1.06 & $0 \cdot 08$ & - & \multirow{4}{*}{ Ald -1} & $1 \cdot 05$ & 0.06 & 0.01 \\
\hline & 1 & 0.92 & 1.00 & & 1 & 0.94 & 0.97 \\
\hline & $\mathrm{N}$ & 19 & 16 & & 0.94 & - & $0 \cdot 02$ \\
\hline \multicolumn{2}{|c|}{ mean het. } & $0 \cdot 16$ & - & & $\mathbf{N}$ & 24 & 34 \\
\hline \multirow[t]{3}{*}{$I d h-1$} & $1 \cdot 06$ & $0 \cdot 01$ & - & \multicolumn{2}{|c|}{ mean het. } & $0 \cdot 12$ & $0 \cdot 06$ \\
\hline & 1 & 0.99 & $1 \cdot 00$ & \multirow[t]{2}{*}{ Ald -2} & 1 & $1 \cdot 00$ & 1.00 \\
\hline & $\mathrm{N}$ & 94 & 90 & & $\mathrm{~N}$ & 24 & 25 \\
\hline \multicolumn{2}{|c|}{ mean het. } & 0.02 & - & \multicolumn{2}{|c|}{ mean het. } & - & - \\
\hline \multirow[t]{2}{*}{$6 P g d h$} & 1 & $1 \cdot 00$ & $1 \cdot 00$ & \multirow[t]{2}{*}{$T p i$} & 1 & $1 \cdot 00$ & $1 \cdot 00$ \\
\hline & $\mathrm{N}$ & 25 & 24 & & $\mathbf{N}$ & 10 & 31 \\
\hline mean het. & & - & - & mean het. & & - & - \\
\hline
\end{tabular}

frequencies are reported in tables 1 and 2. The value of mean genetic distance obtained: $D=0 \cdot 024$, is tenfold higher than that indicated by Harrison and Vawter (1977). These findings show clearly how values of genetic distance can be influenced by the choice of loci.

A separate analysis of genetic distance for the two classes of enzyme loci (variable-substrate and regulatory on the one hand and non regulatory on the other) gives, respectively, $D_{f}=0 \cdot 056 \pm 0.018$ and $D_{s}=0 \cdot 004 \pm 0.005$. In order to test whether the values of $D$ for the two classes of enzyme loci are significantly different we have used the test of comparison of sample means for unpaired observations and unequal variances; according to normal approximation, the following equation can be written:

$$
u \simeq \frac{m_{s}-m_{f}}{\sqrt{\frac{s_{s}^{2}}{n_{s}}+\frac{s_{f}^{2}}{n_{f}}}}
$$

where $m_{s}$ and $m_{f}$ are the mean values of genetic distance respectively among non regulatory and regulatory plus variable-substrate enzyme loci, $s_{s}^{2}$ and $s_{f}^{2}$ are the variances within each of the two classes considered, and $n_{s}$ and $n_{f}$ 


\section{TABLE 3}

Genetic identity (I) and genetic distance (D) for non regulatory and variable substrate plus regulatory enzyme loci in two pheromone strains of $\mathrm{O}$. nubilalis

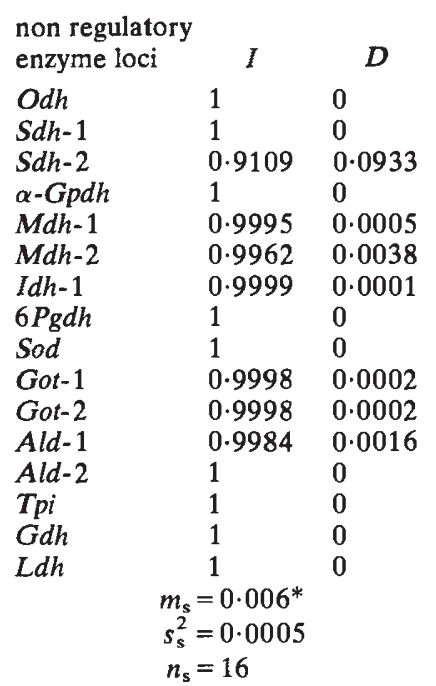

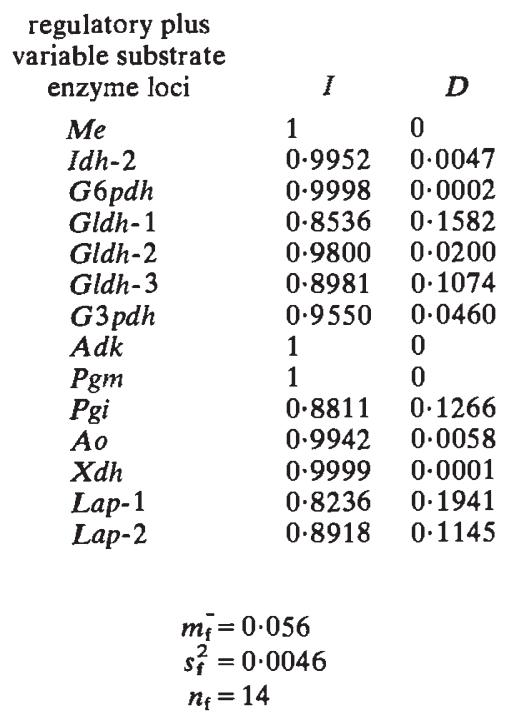

* The existence of a small discrepancy between this value and that given in the text $(0 \cdot 004)$, is due to the different calculations adopted: here $m_{\mathrm{s}}$ is the arithmetic mean of the values of $D$ for each locus of the class, while the mean value of $D_{\mathrm{s}}$ reported in the text is calculated directly from the allele frequencies according to Nei's formula (for a discussion on this point, see Nei, 1972).

are the number of enzyme loci in each class (table 3 ). The value obtained is $u \simeq 2.63$, which is highly significant $(P<0 \cdot 01)$. A similar level of significance $(P<0.01)$ is obtained using the following formula of Cochran and Cox test,

$$
t^{\prime}=\frac{w_{1} t_{1}(0 \cdot 01)+w_{2} t_{2}(0 \cdot 01)}{w_{1}+w_{2}}
$$

where $w_{1}=s_{s}^{2} / n_{s}, \quad w_{2}=s_{f}^{2} / n_{f}, t_{1}(0 \cdot 01)$ and $t_{2}(0 \cdot 01)$ are the values of Student's $t$ for $n_{s}-1$ and $n_{f}-1$ degrees of freedom respectively, at $0 \cdot 01$ level of probability; $t^{\prime}$ lies between the tabulated $t$ values for $n_{s}-1$ and $n_{f}-1$ degrees of freedom. The value obtained is $t^{\prime}=3 \cdot 009$, which is significant at the chosen level of probability $(P=0 \cdot 01)$.

The value of $D_{s}$ we obtained is similar to that given by Harrison and Vawter (1977) on the 10 loci previously mentioned, 80 per cent of which code for non-regulatory enzymes.

The ratio $D_{f} / D_{s}$ between the two pheromone strains of $O$. nubilalis is 14 . Comparable values have been found by Zimmerman et al. (1978) among geographic populations in the genus Peromyscus. Ratios $D_{f} / D_{s}$ of about 10 were observed among subspecies of the genus Peromyscus, and similar ratios were found between sibling species in the Aedes mariae complex (Cianchi et $a l ., 1978)$. The discrepancy between the two values $\left(D_{f}\right.$ and $\left.D_{s}\right)$ apparently decreases with increasing divergence among the taxa considered as pointed out by Sarich (1977). 
If the correlation between the metabolic function of an enzyme and its rate of evolution, as found in Peromyscus, Aedes and Ostrinia, is confirmed in other organisms, the use of mean genetic distance might become meaningless. Values of the genetic distance calculated separately for the two classes of enzymes, variable-substrate and regulatory on the one hand and non-regulatory on the other, and/or the use of samples of loci including comparable percentages of the two classes of loci, would appear to be desirable, particularly in evaluating genetic distances between taxa at the first stages of evolutionary divergence.

\section{REFERENCES}

ANGLADE, P. 1974. Emploi de phéromones sexuelles synthétiques pour l'attraction des mâles de la Pyrale du Mais ( $O$, nubilalis HBN). Rev. Zool. agric. Pathol. vég., 73, 37-46.

AYAlA, F. J., POWELl, J. R., TRACEY, M. L., MOURÃO, C. A., AND PÉREZ SALAS, S. 1972. Enzyme variability in the Drosophila willistoni group. IV. Genic variation in natural populations of Drosophila willistoni. Genetics, 70, 113-139.

CARDE', R. T., KOCHANSKY, J., STIMMEL, J. F., WHEELER, A. G. JR., AND ROELOFS, W. L. 1975. Sex pheromone of the European corn borer (Ostrinia nubilalis); cis- and transresponding males in Pennsylvania. Environ. Ent., 4, 413-414.

CARDE', R. T., ROELOFS, W. L., HARRISON, R. G., VAWTER, A. T., BRUSSARD, P. F., MUTUURA, A., AND MUNROE, E. 1978. European corn borer: pheromone polymorphism or sibling species? Science, 199, 555-556.

CIANCHI, R., URBANELLI, S., COLUZZI, M., AND BULLINI, L. 1978. Genetic distance between two sibling species of the Aedes mariae complex (Diptera, Culicidae). Parassitologia, 20, 39-46.

HARRIS, H., AND HOPKINSON, D. A. 1977. Handbook of enzyme electrophoresis in human genetics. North Holland Publ., Amsterdam.

HARRISON, R. G., AND VAWTER, A. T. 1977. Allozyme differentiation between pheromone strains of the European corn borer, Ostrinia nubilalis. Ann. Ent. Soc. America, 70, 717-720.

JOHNSON, G. B. 1974. Enzyme polymorphism and metabolism. Science, 184, 28-37.

KLUN, J. A., AND COOPERATORS. 1975. Insect sex pheromones: intraspecific pheromonal variability of Ostrina nubilalis in North America and Europe. Environ. Ent., 4, 891-894.

KLUN, J. A., AND MAINI, S. 1979. Genetic basis of an insect chemical communication system: the European corn borer. Environ. Ent., 8, 423-426.

KLUN, J. A., AND ROBINSON, J. F. 1971. European corn borer moth: sex attractant and sex attraction inhibitors. Ann. Ent. Soc. America, 64, 1083-1086.

NEI, M. 1972. Genetic distance between populations. American Naturalist. 106, 283-292.

NEI, M. 1975. Molecular population genetics and evolution. North Holland Publ., Amsterdam.

POWELL, J. R. 1975. Protein variation in natural populations of animals. Evolutionary Biology, $8,79-119$.

ROELOFS, W. L., CARDE', R. J., BARTELL, J., AND TIERNEY, P. J. 1972. Sex attractant trapping of European corn borer in New York. Environ. Ent., 1, 606-608.

SARICH, V. M. 1977. Electrophoresis in evolutionary studies: rates, sample sizes and the neutrality hypothesis. Nature, 265, 24-27.

SELANDER, R. K., SMITH, M. H., YANG, S. Y., JOHNSON, W. E., AND GENTRY, J. B. 1971. Biochemical polymorphism and systematics in the genus Peromyscus. I. Variation in the old field mouse (Peromyscus polionotus). Studies in Genetics, 6, Univ. Texas Publ., 7103, 49-90.

SHAW, C. R., AND PRASAD, R. 1970. Starch gel electrophoresis-a compilation of recipes. Biochem. Genet., 4, 297-320.

ZIMMERMAN, E. G., KILPATRICK, C. W., AND HART, B. J. 1978. The genetics of speciation in the rodent genus Peromyscus. Evolution, 32, 565-579. 